\title{
ADULT LEARNING: TRENDS AND OPPORTUNITIES IN THE ORGANIZATION
}

\author{
Janina Čižikienè \\ Audronė Urmanavičienė \\ Mykolas Romeris University, Lithuania
}

\begin{abstract}
The European Union's education and lifelong learning policy stresses informal learning within the society. The article aims to review the concept of lifelong learning and to analyze opportunities for continuous learning process in organizations. New technologies, innovations in the workplace and professional training encourage employees to improve constantly and awareness of the importance of lifelong learning can help to secure their future in a changing labor market. Research methods applied were as following: literature and document analysis, expert interviews, analysis of the results and interpretation. The article presents a review of scientific literature and research data reveals leaders' approach to employees' willingness to raise their qualification constantly and the organization's opportunities. The survey showed that employers want to have a highly qualified staff meeting the requirements of the organization, but do not always have sufficient funds for professional development.
\end{abstract}

Keywords: adult education, lifelong learning, the organization's activities.

\section{Introduction}

The European Commission emphasizes that in a quickly changing world, life-long learning should be a priority: learning is the essence of employment, economic success and a wholesome community. In order to increase and widen the adults ${ }^{6}$ involvement in life-long learning process, the European Union set a goal of 15 per cent of adults participating in life-long learning. Therefore, it is very important to integrate learning into adults' life. Ensuring adult's life-long learning is relevant because as the society ages, it is forecasted that until the year 2025 , the number of elderly people will rise by 15 per cent and the number of economically active people (ages 15 to 64) will decrease by 10 per cent (ES Tarybos...). Life-long learning develops personal improvement and increases economical competitiveness. Employees that are not learning are less productive and susceptive to novelties which makes it harder for them to find a place in the labor market. One of the biggest problems of adults" learning is the compatibility of learning supply and demand and if those learning really find accessible, proper learning services that meet their personal and public needs in the learning market as well as if they are offered required knowledge satisfying 
their skills. Also, a learning person always experiences contradiction about the knowledge obtained and skills trained. Therefore, a person starting to learn should be ready and have a particular motivation to learn. Secondly, the person should have the skills and abilities to accept and comprehend the new values of learning and subjects. Although learning skills obtained quite often become a very strong motivation, it is important that the person's education and wish to develop in the organization is valued as well.

In Lithuania, (Laurinavičiūte, 2001) wrote about the assumptions of adult learning. Janulienè \& Veršinskienè (2003) review the efficiency and barriers of adult learning, (Gudelienè - Gudelevičienè \& Kaušylienè, 2006) examined the change of education paradigm, from teaching to learning. Abramauskienė \& Kirliauskiene (2008) stated that a learning person always experiences contradiction about the knowledge obtained and skills trained. The peculiarities of integration into labor market and life-long learning were also reviewed (Žalimienè et al., 2011). Life-long learning achievement evaluation was analyzed by Laužackas (2005), Teresevičienè et al., (2006), Fokienė \& Sajienė (2009), Stasiūnaitienė (2008), Žemaitaitytė (2007), Burkšaitienė \& Šliogerienè, (2010) and others. Foreign authors (Baldwin \& Ford, 1988) studied the model of knowledge application in practice, (Holton, 1996) distinguished the factors which influence knowledge application in work. Dessler (2001) discussed effective teaching programs for adults, (Boeren et al., 2010), (Dermol, 2012) analyzed the influence of leaders and colleagues on the person learning distinguishing that supervision, support and motivation from leaders and colleagues are fairly important in the organization. Renta-Davids et al., (2014) examined the theory of examples identical to work.

The goal of the article is to review the life-long learning conception and to analyze the possibilities of continuous learning process in organizations. To reach the goal, the following assignments were formed: to define the concept of life-long learning; to review the peculiarities of adult learning process and to analyze the conditions allowing increasing adults' learning motivation in organizations. Qualitative research method was chosen to carry out the empirical research - research of experts' opinion in a form of a structured questionnaire (an interview). The research was carried out by conducting a formal interview, i.e. an interview following questions formulated in advance, all of which were given to the interviewed in the same order. This form of interview was chosen with a strive to find out experts' opinion about the present situation and by comparing answers to reveal the experts' attitude to adult learning motivation and real opportunities allowing people to improve and learn while working in organizations.

The questionnaire consists of a group of questions related with each other, which the questioned experts had to answer. The research was conducted on 
October, 2015 in Vilnius, Lithuania. It consisted of the following stages: preparation of research instrument, interview and analysis of research data.

\section{The concept of life-long learning}

The European Union Memorandum of Lifelong learning (2000) has spread the concept of lifelong learning in the countries of European Union. The document reveals lifelong learning not only on an economical attitude, but also takes into account the citizens' employment possibilities, striving to train their abilities, civil education and involvement into social activities. The Memorandum describes the learning person's equal opportunities to improve in the process of learning. The memorandum distinguishes the following main theses: 1) skills and main abilities are for everyone, which means that every individual should acquire and master such skills and abilities which would allow to properly entrench in public and social life, created conditions to improve; 2) it should be invested into human resources as much as possible by creating a more flexible financing system, thus attracting individuals to improve; 3) novelties should be implemented in learning and teaching to attract more people for educative purposes, also to apply various methods and forms in the process; 4) learning should be evaluated properly, formal and informal ways of learning should have their accreditation systems; 5) consultation and orientation systems should be reviewed and with the help of consultations in particular to make learning more accessible for everyone; 6) lifelong learning conditions should be created close to the learning, in their communities and where possible to implement computer technologies. Thus, lifelong learning in the EU is, was and will be one of the main political means allowing seeking for competitiveness and social cohesion in modern global world economy.

In Lithuania, lifelong learning conception was legitimated in 2004 after approving Lifelong learning ensuring strategy, the "goal of which is to develop comprehensive, integral and high quality lifelong learning system which offers opportunities for versatile education and professional life of all individuals of working age" (Totoraitis \& Tarasevič, 2009). The Lithuanian Republic law on education (2006) notes that the purpose of Lithuania's education is to ensure universal possibility of accessing mandatory education for all citizens of the Republic of Lithuania and foreign citizens who have the right to permanently or temporarily live in Lithuania.

In 2012, Seimas of the Republic of Lithuania approved Country development strategy "Lithuania 2030" which mentions "lifelong learning as one of the main factors ensuring Lithuanian society's readiness for world change and enabling the creation of clever society". "Lithuania 2030" development strategy vision is clever Lithuania. Society must become constantly learning, 
solid and active. Every citizen should be responsible, creative and open for changes. Every individual could integrate into national and international society of self-dependent people, thus independently creating one's own success, national culture and advanced economy. Due to this reason, the education system of Lithuania should involve all Lithuanian people into an advanced education society, motivate to constantly improve and purposefully learn, seeking for personal benefit and success for one's country.

All in all, a conclusion could be made that lifelong learning is constant improvement of an individual, which allows him to adapt to modern labor market changes, i.e. both when searching for a job and increasing qualification in the present job. In addition, lifelong learning motivates people to take part in social activity, thus developing new competences.

\section{Adult learning process}

Literature highlights that the need of adult learning is influenced by internal and external factors. Internal factors cover individual adult needs in different stages of career, different stages of socialization in an organization. External motive group consists of attestation requirements, organizational competence needs, professional work quality ensuring etc. Also, adult teaching motivation and factors strengthening are important (Barkauskaite, 2006). Learning process should be coordinated with adult motives which determine their wish to learn, their choice of learning forms. Adult learning organization is based on modern adult education principles and teaching theories (Knowles, 1980): adults are more self-dependent; they are less dependent on other people, are able to create a learning environment; they invoke their experience which influences the determination to learn and value learning; they go over different growth stages which form attitude to learning; adults learn with a goal in mind; if they are forced to learn, it does not mean that they will accumulate the knowledge; adults focus their attention to problems and apply everything they have learned to solve them. According to experiential learning model formed by (Kolb, 1984), an individual with particular experience or having carried out observations and reflecting experience develops abstract theories and conclusions in topics of observations or reflections. Kolb (1984) claims that theoretical knowledge of a learning individual should be closely related to practical competences and real activity. Reflexive experience is important, which consists of the following: formulation of a problem in a situation; problem determination based on accumulated experiences; comprehension of the problem's parts and knowing of the problem's solution. Pierce \& Fenwick (2005) discuss adult learning models and distinguish a model of reflexive exploration, which emphasizes the learning individual's personal experience in the learning process: experience is 
exchanged, one's practical work, functions are presented etc. The organization of adult learning process differs (Juozaitis, 2006), (Mažeikis, 2007) distinguishes the following adult learning forms: observation/evaluation of colleagues; reflection; study groups, project groups; problem formulation, work research; work lead by an adviser; networks; portfolio of competences; simulation games; participation in forums, debates; computerized learning or learning with the help of video medium. In modern adult learning, experiential learning forms prevail which provide opportunities to obtain experience satisfying the needs of those learning in different stages of improvement.

Learning process covers: the one learning, educator and environment. It should be noted that the conception of an adult as a participant in learning process is changing, because the meaning of self-directed learning is emphasized. Self-directed learning perspective emphasizes that a learning individual can manage the learning process himself: planning, realizing, evaluating. An adult is a self-directed learner who is able to plan and realize learning as one's own lifelong improvement condition (Jarvis, 2001).

The educators role and assignment also changes: educators have to constantly search for new qualitative forms and methods of learning, teach not only fundamental and applied knowledge, but also work methods, problem solving enabling those learning to act in changing situations, create and environment in which learning individuals would be active information receivers and could apply earlier experience and knowledge (Teresevičienè et al., 2004). When creating an educational environment, it is important to follow these main values attention to the one learning, authentic conditions and context, evaluation of the learning individual's experience, use of technologies. Environment is described as a dynamic learning activity space, created and affected by the educator and conditioned by education goal, contents appropriate to the goal, education forms, methods and tools (Jucevičienè et. al, 2010). Speaking of adult learning environments, it is important to ensure possibility to directly and practically test new knowledge and skills, collaborate and learn from colleagues; learning should be analyzed reflectively as well. It is important to ensure proper climate and culture. According to Evans \& Mohr (1999), adult learning peculiarities are: learning is an individual process, but works best in a group; learning should provide opportunities for purposive reflection; learning is more successful when adults project their learning process themselves; learning should allow the obtained knowledge to be tested in practical activity. Goldring et al., (2010) distinguish the following adult learning principles: education content should reflect individual needs of those learning in different learning stages; continuous learning applying various experiential learning forms; consistent education content reflecting everyday needs and connection with 
workplace; competent educators able to always consult and collaborate, help solve problems, consistent and fair evaluation of competence education results.

In conclusion, adults learn having a set goal in mind, whereas if they are forced to learn, it does not mean that they will accumulate knowledge; adults focus their attention to problems and apply everything they have learned to solve them. It is important that adult learning process ensures a possibility to directly and practically test new knowledge and abilities, collaborate and learn from others; learning should be analyzed reflectively as well.

\section{Organization's influence on learning}

When analyzing adult learning perspectives, organization's influence is distinguished, because a person spends the bigger part of his life in an organization (Senge, 1990). Learning is influenced by employers and employees reciprocal relations. It also depends on employers' attitude to continuous learning and organizational culture. Continuous improvement is a goal of every good organization and learning is an assumption of a successful organizational activity. Employees should constantly improve, they should be educated, motivated to work better, flexibly react to clients' complaints, adapt to their needs etc. (Šalkauskienè et al., 2006), because consumers form their opinion on the organization from how the organization's employees serve them and how qualitatively they are able to provide the necessary.

Employee training in organizations is becoming an inseparable part of the strategy. Seeking to provide employees with possibilities to improve, it is mandatory to ensure proper education process which should be consistent, planned and controlled. Dessler (2001) names the following stages of education process which may help to create programs and ensure successful education in an organization: 1) necessity analysis. The goal is to help determine the need of training. In the process of necessity analysis it is sought to find out what employees' skills should be improved, what knowledge should be provided in order to improve the quality and efficiency of their functions. After analyzing employees' characteristics and skills, functions should be divided into separate assignments so that it is possible to concentrate on training how to accomplish them later on. After determining training necessity, results and goals of achievements reached during training are formulated. 2) Design of teaching process, formulation of final teaching goals and choice of methods. If seminars for employees' education are chosen outside the organization or with the help of third party, the programs offered should be familiarized and it should be ensured that the program satisfies the employee's needs, systematic teaching program should be created. All education means, practical and theoretical parts of training should supplement each other, thus forming a systematic teaching 
program. 3) Verification of training efficiency. Conducting training may help to see the program's flaws and weak sides. 4) Realization stage. All planned activities take place, training program is conducted. 5) Evaluation and consolidation of training results. When evaluating a training program, attention should be paid to evaluation structure, its creation and determination of results based on which the program will be evaluated. According to Dessler (2001), successful and effective training program can only be created based on consistent steps which cover the evaluation of training necessity, creation of the program, verification, realization and evaluation of the program. If education process planning is approached from a managerial perspective, it is recommended to invoke principles of systematicity, expedience and efficiency. Systematicity manifests when long term education plans are created, they are expanded into specific periods of time and education process is controlled. Education process is expedient when strategic goals of the organization or its subdivisions and needs for employee training are taken into consideration. The problem of efficiency is solved by setting up target employee groups which will require education and by creating programs of methodological and problematical level. Efficiency should ensure a favorable environment for applying new skills and knowledge in the organization. Not only use of competences is important, but also their spread in the whole organization.

In conclusion, it could be stated that employee training in an organization should firstly conform the organization's goals. Organizational leadership that comprehends the importance of employee training could help increase the quality and efficacy of functions carried out by employees and create favorable learning conditions both in the organization and outside it.

\section{Analysis of experts' (leaders') opinion}

The aim of in-depth interview was to find out the leaders' opinion on employee self-improvement, their abilities and wish to improve and seek for new knowledge. Leader interview helped to determine the aspects of adult lifelong learning, analyze the possibilities of self-improvement of organization's employees, make clear the tendencies and problems that prevail in organizations. Leaders were ensured of their answers' anonymity, without confronting ethical principles. All informants were acquainted with the goal and use of the research, questions on confidentiality were also discussed. Five leaders of business organizations providing support services (criteria: leadership in business and work experience of management more than three years) were questioned by a questionnaire prepared in advance, which consisted of a group of inter-related questions. Problem questions: What are the possibilities for and employee in your organization to improve? What abilities should employees of 
Janina Čižikiené, Audrone Urmanavičiene. Adult Learning: Trends and Opportunities in the Organization

your organization improve? What reasons determine employees' motivation to learn? How much time and effort do employees have to assign for improvement and learning? What are the employees' expectations for the organization when seeking constant improvement?

During the interview leaders indicated the opportunities to constantly improve the employees are provided with: "our employees work with computer equipment, have to get acquainted and learn how to work with new computer programs", "after installing new programs, we invite a specialist who introduces the program and trains employees", "employees are properly prepared for working with new programs, new employees are trained", "employees always have an opportunity to improve in courses at times convenient for them, but work hours are taken into consideration, a work schedule is created so that courses do not interfere with work process", "it is very important to improve employees' communicational skills and organizational behavior", "training constantly take place, seminars and various courses are organized in fields of communication, management and psychology", "if training is interesting for employees themselves, they take part willingly, express their opinion, I think that such training delivers new ideas", "organization's employees should constantly train in seminars because it is mandatory for the renewal of license", "employees willingly go to training courses". It was sought to make clear what training is the most common and what abilities employees should improve. The leaders noted: "employees constantly improve their computer work skills, but it is also mandatory for them to gain skills in communication with clients", "English language knowledge should be improved, because our organization often has guests from abroad", "foreigners are also our clients, therefore our employees must know English", "due to collective being quite big, often interpersonal disagreements between employees emerge, which highly hinders work quality, it would be good to learn how to solve interpersonal conflicts", "foreign language knowledge should be improved, because seminars are often in English".

The analysis of research data shows that when a new employee is hired for

appropriate position, education and work experience are taken into consideration, however: "work experience is not always mandatory, but having work experience makes the possibility of employment higher", "if there are several candidates to a position, the one with higher work experience and appropriate education is preferred", "students are hired because they seek education and the majority of them has a wish to earn money as well", "due to our organization providing physiotherapy services, education in this field is absolutely mandatory for the employee, work experience is desired as well".

It is interesting to note that employees' motivation to learn depends on the employee's wish to work better, his efforts and dedication for work: "it can 
partly depend on education received during years of studies, but it depends more on the employee's position in the organization", "if position in an organization does not require a particular education, motivation to learn may not depend on it", "employees' motivation highly depends on their education, which, of course, provides the employee with a right to work and constantly improve", "without proper education, employees could not provide our clients with any services".

The informants distinguished the employees' wish to learn and improve:

"if the employee shows a wish to learn and improve, we always try to provide him with knowledge he lacks", "we ask employees with more knowledge and higher skills to help others, thus promoting collaboration", "employees may improve their personal skills which are required to accomplish some particular work in the organization", "organization's profit directly depends on the employees' efforts, therefore they should be motivated to seek for perfection, only that way the organization may expect good results and profit", "when providing services for people, it is necessary to spend as much time for improvement in the professional field, because it is a very responsible work, which requires good professional knowledge, which influence organization's success and image". Leaders state that employee's motivation to improve, willingness to work for the good of the company and satisfy one's needs is the most important: "a person who understands the perspectives of learning is more flexible, more easily adapts to environment and is more motivated to work", "overcomes difficulties and problems easier, is more curious and motivated", "sometimes an employee who worked in a particular field for his whole life has the required knowledge and experience in his work, then he has had enough of learning", "if a person is not interested in the novelties of his field, it is very hard to enforce him to do so and it is an employee we do not tolerate, because the job is too responsible". It was sought to find out how employees are motivated to learn and using what means: "when employees have enough knowledge and abilities to accomplish assignments assigned to them, they feel good in the work collective", "there were cases when an employee wanted to cancel employment contract because he felt that he was unsuitable for the job because he did not have the required skills. We sent him to training and now he works very well", "our employees are competent enough, but willingly go to seminars, then exchange experience", "our organization motivates every member of the organization to perceive his wishes, goals, expectations and to link them with organizational goals", "we motivate collaboration, various joint work is organized during training", "there is a common attitude in the organization that it is necessary to learn and improve and to apply the obtained knowledge in practice", "we use various forms of motivation to motivate learning". 
Concluding the analysis of in-depth interview with leaders it can be stated that employees' education and experience is very important. The higher competence the job requires or the higher level leader is hired, the higher qualification and education is expected. Work productivity does not always depend on the employees' education as well.

The leaders questioned mentioned that employee's willingness to work, motivation and wish to improve is very important. The employees of all organizations the leaders of which took part in the survey are constantly training in their field. This was confirmed by the organization leaders. They claim that it is important that employees improve their professional abilities, skills of communication with clients, English language knowledge and skills of communication with each other. We can make an assumption that employee self-improvement is important both for the organization and the employee. All leaders answered positively that the majority of employees are sufficiently motivated to train and seek new competences, but employers would like the employees to train in their workplace or leave their workplace for as little time as possible.

\section{Conclusions}

Lifelong learning is a constant individual's improvement which allows the individual to adapt to the changes of modern labor market both when trying to get employed or when raising qualification in the job they are in. Motives of adult learning may be various, both internal and external. Internal motives cover personal striving for improving, gaining new competences which may not always be linked to direct functions of work accomplishment. External motives are various certification requirements, organization's competence needs etc. In the adult learning process the adults rush to apply everything they have learned to solve problems which is why it is important to ensure possibilities to directly and practically test out new knowledge and abilities, collaborate and learn from colleagues. Employee training in an organization should firstly meet the organization's goals. Organizational leadership should actively participate in the training process, i.e. when training programs are created, leaders should observe how they are realized, choose employee training methods etc. The analysis of leaders' in-depth interview revealed that leaders find employees' willingness to work, motivation and wish to improve important. All leaders answered positively that the majority of employees are sufficiently motivated to train and seek new competences, but employers would like the employees to train in their workplace or leave their workplace for as little time as possible. 


\section{References}

Abramauskienè, J., \& Kirliauskienè, R. (2008). Suaugusiuju mokymosi motyvacija. Pedagogika, 89, 58-63.

Adult and continuing education in Europe. Downloaded from: http://ec.europa.eu/research/ social-sciences/pdf/kina25943enc.pdf

Barkauskaitè, M. (2006). Suaugusiuju pedagogikos gairès. Vilnius: VPU.

Baldwin, T. T., \& Ford, J. K. (1988). Transfer of training: A review and directions for future research. Personnel Psychology, 41, 63-105.

Boeren, E., Nicaise, I., \& Baert, H. (2010). Theoretical models of participation in adult education: the need for an integrated model. International Journal of Lifelong Education, 29, 45-61.

Bush, T. (2008). Leadership and management in education. London: Sage.

Burkšaitienė, N., \& Šliogerienè, J. (2010). Neformaliojo ir savaiminio mokymosi pasiekimu vertinimas ir pripažinimas universitete. Vilnius: MRU.

Burkšaitienè, N., \& Šliogerienè, J. (2012). Neformaliojo ir savaiminio mokymosi pasiekimu vertinimas ir pripažinimas aukštojo mokslo institucijose: taikomasis mokslo darbas. Vilnius: MRU

CEC. (2000). Commission staff working paper. A Memorandum on Lifelong Learning. Downloaded from: http://arhiv.acs.si/dokumenti/Memorandum_on_Lifelong_ Learning.pdf

Dermol, V. (2012). Synergetic effects of training and training transfer factors in organisations. International journal of management in education, 6, 212-227.

Dessler, G. (2001). Personalo valdymo pagrindai. Kaunas: Poligrafija ir informatika

Europe (2020). Downloaded from: http://ec.europa.eu/europe2020/index_en.ht.

Europos bendriju komisija. Komisijos komunikatas Suaugusiuju mokymasis: mokytis niekada nevèlu (2006). Downloaded from: http://eurlex.europa.eu/LexUriServ/ LexUriServ.do?uri=COM:2006:0614:FIN:LT:PDF.

Europos Sajungos pranešimas apie mokymasi visq gyvenima (2001). Downloaded from: http://ec.europa.eu/lietuva/documents/power_pointai/sutinyte.ppt\#278,1

Eurostat Statistics. Downloaded from: http://epp.eurostat.ec.europa.eu/statistics_explained/ index.php/Lifelong_learning_statistics

Europos Sajungos Tarybos rezoliucija dèl atnaujintos Europos suaugusiuju mokymosi darbotvarkès, 2011-12-20, 1 priedas, 1 . Downloaded from: http://eurlex.europa.eu/legal-content/LT/TXT/?uri=CELEX\%3A32011G1220(01)

Evans, P., \& Mohr, N. (1999). Professional development for principals: Seven core beliefs. Phi Delta Kappan, 80 (7), 530-532

Holton, E. F. (1996). The flawed four-level evaluation model. Human Resources Development Quarterly, 7 (1), 5-21.

Duvekot, R., Pukelis, K., \& Fokienè, A. (2010). Ankstesniojo mokymosi pasiekimu vertinimas profesijos mokytoju rengime. Vadovas vertintojams. Kaunas: BlticPrint \& Banners

Fokiene, A., \& Sajienè, L. (2009). Portfolio metodas vertinant neformaliojo ir savaiminio mokymosi pasiekimus. Aukštojo mokslo kokybè, 6, 141-159.

Goldring, E. B., Preston, C., \& Huff, J. (2010). Conceptualizing and evaluating professional development. Paper presented for the Asian Leadership Roundtable. Institute of Education, Hong Kong.

Gudelienè- Gudelevičienè, L., \& Kaušylienè, A. (2006). Ugdymo paradigmos virsmas: nuo mokymo prie mokymosi. Pedagogika, 82, 68-72. 
Janina Čižikienè, Audrone Urmanavičienè. Adult Learning: Trends and Opportunities in the Organization

Illeris, K. (2002). The Three Dimensions of Learning. Contemporary learning theory in the tension field between the cognitive, the emotional and the social. UK: NIACE.

Jarvis, P. (2001). Mokymosi paradoksai. Kaunas: VDU.

Jarvis, P. (2006). Towards a Comprehensive Theory of Human Learning. London and New York: Routledge.

Jarvis, P., Holford, J., \& Griffin, C. (2004). The Theory and Practice of Learning. London: Routledge

Jucevičienè, P. et. al. (2010). Universiteto edukacinè galia: atsakas XXI amžiaus iššūkiams: mokslo monografija. Kaunas: Technologija.

Janulienè, I., \& Veršinskienè, R. (2003). Teorinis suaugusiujų mokymo/mokymosi aspektas: efektyvumas ir barjerai. Profesinis rengimas: tyrimai ir realijos.

Juozaitis, A. M. (2006). Besimokantieji suaugusieji. Vilnius: LSŠA.

Knowles, M. S. (1984). The Adult Learner: A Neglected Species. Houston, TX: Gulf.

Knowles, M. S. (2005). The adult learner: the definitive classic in adult education and human resource development. Oxford: Elsevier.

Knowles, M. S., Holton, E. F., \& Swanson, R. A. (2007). Suaugęs besimokantysis: klasikinis požiūris i suaugusiuju švietimq. Vilnius: Danielius.

Kolb, D. A. (1984). Experiental Learning: Experiance as the Source of Learning and Development. Englewood Cliffs, N. J.: Prentice Hall. Downloaded from: http://academic.regis.edu/ed205/kolb.pdf

Laurinavičiūtè, J. (2001). Suaugusiujų mokymosi samprata. Pedagogika, 55, 49-53.

Laužackas, R., \& Stasiūnaitienè, E. (2005). Mokymosi pasiekimu aplanko ir pokalbio taikymas vertinant neformaliojo ir savaiminio mokymosi pasiekimus. Profesinis rengimas. Tyrimai ir realijos. 9, 46-54.

Laužackas, R., Teresevičienè, M., \& Stasiūnaitienè, E. (2005). Kompetenciju vertinimas neformaliajame ir savaiminiame mokymesi. Kaunas: VDU.

Laužackas, R. (2005). Profesinio rengimo metodologija. Kaunas: VDU.

Lithuanian Republic law on education (2006). Downloaded from: http://www3.lrs.lt/ pls/inter2/dokpaieska.showdoc_1?p_id=279441\&p_query=\&p_tr2

Linkaitytè, G. M., \& Žilinskaitè, L. (2008). Mokymosi visą gyvenimą idejos igyvendinimo perspektyva Lietuvoje. Pedagogika, 89.

Linkaityte, G. M., Šuliakaite, A., \& Navikienè, Ž. (2011). Neformaliojo suaugusiuju mokymosi sampratu analize mokymosi visq gyvenima kontekste. Vilnius: Ugdymosi plètotès centras

Senge, P. (1990). The Fifth Discipline: the Art and Practice of the Learning Organization. New York: Doubleday.

Smith, M. K. (2002). Malcom Knowles, informal adult education, self-direction and andragogy. Downloaded from: http://infed.org/mobi/malcolm-knowles-informal-adulteducation-self-direction-and-andragogy/.

Stasiūnaitienè, E. (2008). Neformaliojo ir savaiminio mokymosi pasiekimų vertinimo ir kompetenciju pripažinimo sistemos organizavimas. Organizaciju vadyba: sisteminiai tyrimai. 45, 57-69.

Šalkauskienė, et al. (2006). Darbuotojų motyvavimo empirinis tyrimas Šiaulių miesto i̇monių pavyzdžiu . Ekonomika ir vadyba: aktualijos ir perspektyvos. 1 (6), 156-162

Mažeikis, G. (2007). Kompetenciju ugdymo sistema taikant kooperuotu studiju metoda. Šiauliai: S̆U.

National Progress Strategy ,Lithuania 2030” Downloaded from: https://rio.jrc.ec.europa.eu/ en/library/national-progress-strategy-lithuania-2030 
Pierce, M. C., \& Fenwick, L. (2005). Professional development of principals. Professional Development From the Inside Out: District and School-level Strategies. The Newsletter of the Comprehensive Center-Region, 8 (1), 32-33.

Pont, B., Nusche, D., \& Moorman, H. (2008). Improving School Leadeship. Volume 1: Policy and Practice. Paris. Downloaded from: http://www.oecd.org/edu/school/44374889.pdf

Renta-Davids, A. I. et. al. (2014). Transfer of learning: Motivation, training design and learning-conducive work effects. European Journal of Training and Development, 38.

Teresevičienè, M., Gedvilienè, G., \& Zuzevičiūtè, V. (2006). Andragogika. Kaunas: VDU

Teresevičienè, M., Oldroyd, D., \& Gedvilienė, G. (2004). Suaugusiuju mokymasis. Andragogikos didaktikos pagrindai. Kaunas: VDU.

Totoraitis, R, \& Tarasevič, I. (2009). Mokymosi visq gyvenima strategija: požiūriu ìvairové. Vilnius: Efrata.

Valstybès pažangos strategijos „Lietuvos pažangos strategija „Lietuva 2030“. Downloaded from: http://www3.lrs.lt/pls/inter3/dokpaieska.showdoc_1?p_id=425517\&p_query=\& p_tr2=2

Valstybinés švietimo strategijos 2003-2012 metu nuostatos. (2003). Downloaded from: $\mathrm{http}: / / \mathrm{www} . \mathrm{smm} .1 \mathrm{t} / \mathrm{teisine} \_$baze/ docs/strategija2003-12.doc

Žalimienè, L., \& Lazutka, R. et al. (2011). Socialinis teisingumas švietime: teorine samprata ir praktinis vertinimas. Vilnius: Švietimo aprūpinimo centras.

Žemaitaitytè, I. (2007). Neformalusis suaugusiuju švietimas: plètros tendencijos dabartineje Europoje. Vilnius: MRU. 